ORNL/TM-2015/21

\title{
Personal Insights and Anecdotes about the Weatherization Assistance Program Process Field Study
}

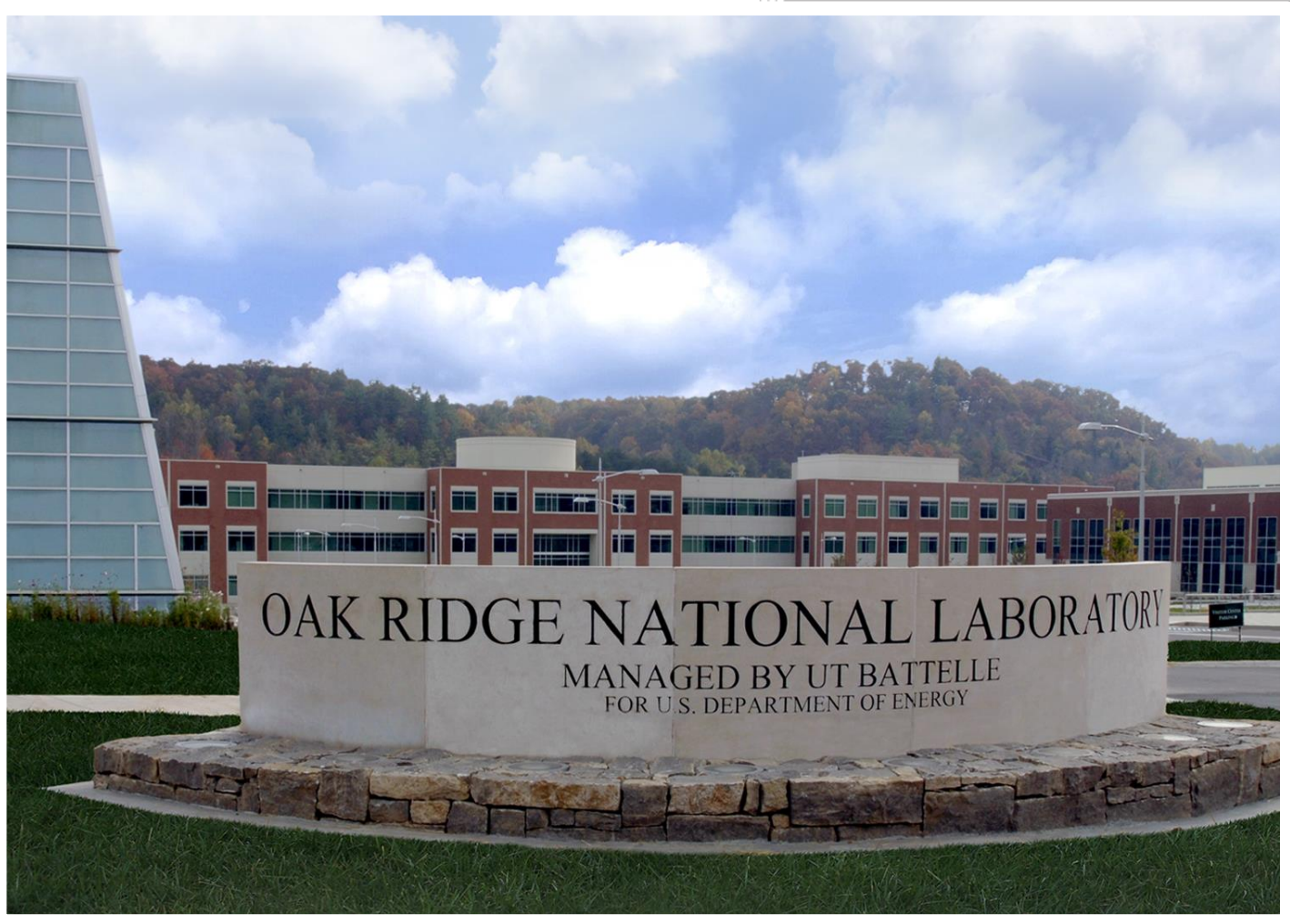

Inga Treitler Judith Gregory

September 2014 


\title{
DOCUMENT AVAILABILITY
}

Reports produced after January 1, 1996, are generally available free via US Department of Energy (DOE) SciTech Connect.

Website http://www.osti.gov/scitech/

Reports produced before January 1, 1996, may be purchased by members of the public from the following source:

\author{
National Technical Information Service \\ 5285 Port Royal Road \\ Springfield, VA 22161 \\ Telephone 703-605-6000 (1-800-553-6847) \\ TDD 703-487-4639 \\ Fax 703-605-6900 \\ E-mail info@ntis.gov \\ Website http://www.ntis.gov/help/ordermethods.aspx
}

Reports are available to DOE employees, DOE contractors, Energy Technology Data Exchange representatives, and International Nuclear Information System representatives from the following source:

Office of Scientific and Technical Information

PO Box 62

Oak Ridge, TN 37831

Telephone 865-576-8401

Fax 865-576-5728

E-mail reports@osti.gov

Website http://www.osti.gov/contact.html

This report was prepared as an account of work sponsored by an agency of the United States Government. Neither the United States Government nor any agency thereof, nor any of their employees, makes any warranty, express or implied, or assumes any legal liability or responsibility for the accuracy, completeness, or usefulness of any information, apparatus, product, or process disclosed, or represents that its use would not infringe privately owned rights. Reference herein to any specific commercial product, process, or service by trade name, trademark, manufacturer, or otherwise, does not necessarily constitute or imply its endorsement, recommendation, or favoring by the United States Government or any agency thereof. The views and opinions of authors expressed herein do not necessarily state or reflect those of the United States Government or any agency thereof.

ORNL Principal Investigator Dr. Bruce Tonn 
Environmental Sciences Division

\section{PERSONAL INSIGHTS AND ANECDOTES ABOUT THE WEATHERIZATION ASSISTANCE PROGRAM PROCESS FIELD STUDY}

Inga Treitler, Anthropology Imagination, Inc. Judith Gregory, Applied Energy Research

September 2014

Prepared by

OAK RIDGE NATIONAL LABORATORY

Oak Ridge, Tennessee 37831-6283

managed by

UT-BATTELLE, LLC

for the

US DEPARTMENT OF ENERGY

under contract DE-AC05-00OR22725 



\section{CONTENTS}

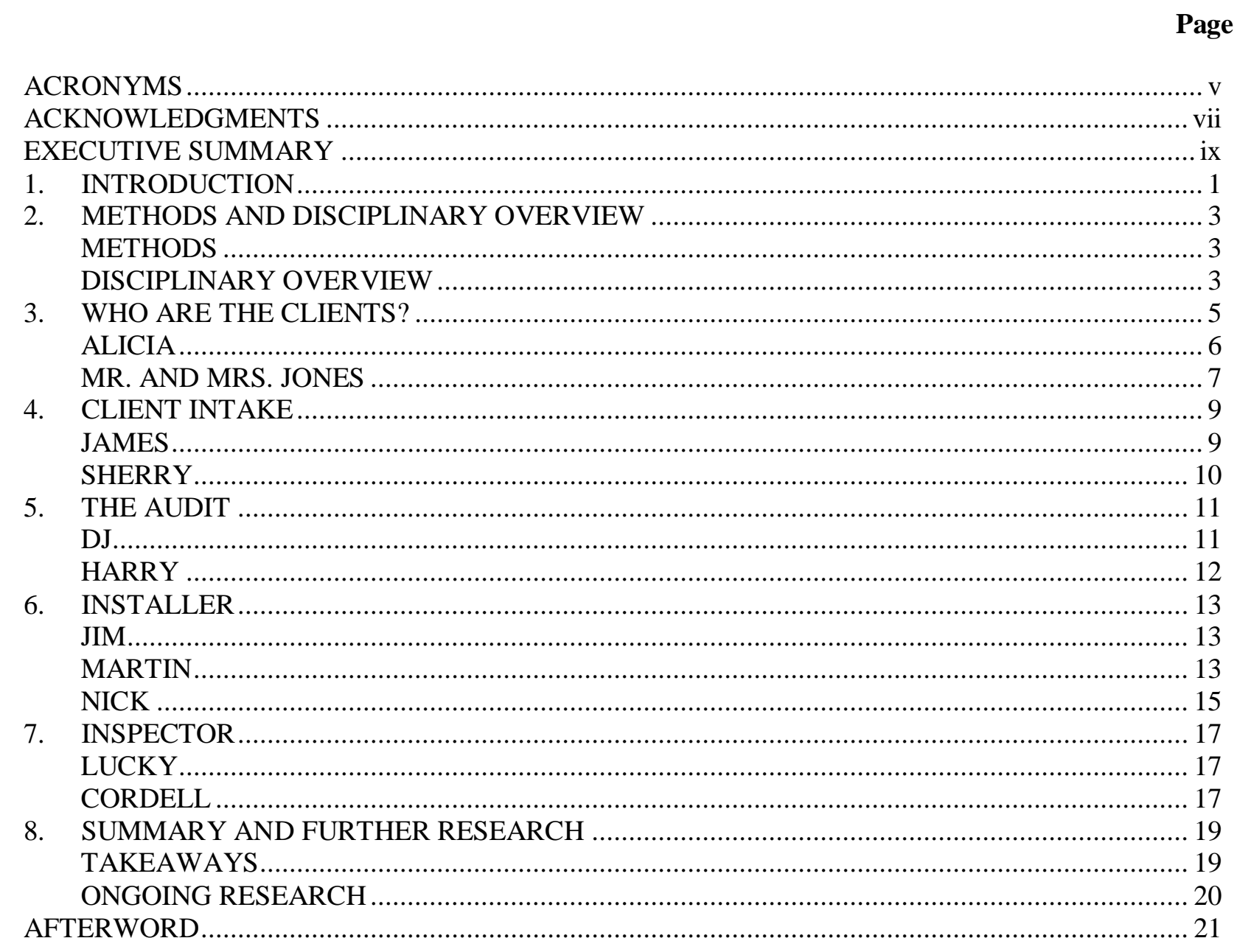





\section{ACRONYMS}

ARRA American Recovery and Reinvestment Act

CAP Community Action Partnership

ORNL Oak Ridge National Laboratory

WAP Weatherization Assistance Program 



\section{ACKNOWLEDGMENTS}

The work presented in this report was funded by the U.S. Department of Energy's (DOE) Office of Weatherization and Intergovernmental Programs (OWIP).

This report was collected by the social scientists of the Weatherization Assistance Program Process Field Study. Contributors who provided substantially to this project include Amanda Rose and Philip Schilling. 



\section{EXECUTIVE SUMMARY}

The present report is based on the research conducted for the Process Field Study between March and September 2011. The Process Field Study documents how Weatherization Assistance Program (W AP) services were delivered to clients, and the quality with which those services were delivered. The assessments were conducted by visiting 19 agencies in 19 states around the country interviewing agency managers, staff, and contractors; observing program intake along, with 43 audits, 45 measure installation and 37 final inspections; and conducting debriefing interviews with clients and weatherization staff following the observation of service delivery. ${ }^{1,2}$ In this report, we turn to detailed observations of a few field interactions.

The client stories from our observations illustrate some of the ways clients and crew interact to build the success of the program, but shows there will always be unanticipated obstacles to building trust and getting the program to the public. Stories of staff and crew career paths indicate that weatherization technology and techniques are being learned and used by technicians out of the new home construction industry and that their new knowledge provides them with technical tools and methods that many hope to take back into the construction industry if and when they return.

This report is organized according to the four stages of weatherization: intake, audit, installation, and inspection. It contributes to our understanding of the area where policy, environment, culture, and individual decisions influence social innovation. The anecdotes reveal the realities of implementing programs for the benefit of the greater good at minimal cost and sacrifice in times of ever restricting budgets. As the authors revisited their field notes and compiled memorable narratives to communicate the essence of the weatherization experience, they identified three key takeaways that summarize the major issues. First, in WAP as in all services there will always be challenges to reaching the community needing to be served. Second, crew and staff learn new skills and gain experience that can be and are applied in jobs elsewhere. Finally, in the best cases, changes from the weatherization experience permeate communities in unanticipated ways.

\footnotetext{
${ }^{1}$ The number of interviews held and number of people interacted with at each site were undocumented.

${ }^{2}$ Details of the larger study's design are available in:

"Berger, J., Lenahan, T., and Carroll, D. 2014. National Weatherization Assistance Program Process Field Study: Findings from Observations and Interviews at 19 Local Agencies Across the Country. ORNL/TM-2014/304, Oak Ridge National Laboratory, Oak Ridge, Tennessee, September.
} 



\section{INTRODUCTION}

It's a culture of crisis [the economic downturn]. People are always on the breaking point. Many people have no ability to respond on their own and it has a domino effect.

Our goal is that $95 \%$ of clients will greet us with a smile.

Intake staff, Massachusetts

Auditor, Texas

If the client is resistant to learning about energy conservation from us, there are still five people in the household who may get the message.

Inspector, Florida

The present report is based on the research conducted for the Process Field Study between March and September 2011. The Process Field Study documents how Weatherization Assistance Program (WAP) services were delivered to clients, and the quality with which those services were delivered. The assessments were conducted by visiting 19 agencies in 19 states around the country interviewing agency managers, staff, and contractors; observing program intake, along with 43 audits, 45 measure installation and 37 final inspections; and conducting debriefing interviews with clients and weatherization staff following the observation of service delivery. ${ }^{3,4}$ In this report, we turn to detailed observations of a few field interactions.

The authors and contributors are four of the social scientists who conducted participant observation alongside the weatherization experts on the WAP evaluation team. As we observed and talked with participants we came to see opportunities created by the program that that go beyond the stated goals of reducing energy costs and increasing health and safety for people at risk. ${ }^{5}$ We think it is important for those findings and insights to become part of the record of the WAP evaluation and that is why we have prepared this report. Here we do several things. First we describe some of the homes we visited and the people living there (the clients), to show readers the range of housing stock and the living conditions and challenges of the people the program has served across this national study. Second we use some of the interactions we had with the crews/staff and the people in the homes, to give examples of ways the program has created opportunities beyond the stated goals. Finally we have collected a few memorable narratives from crews/staff and from the people served that show the range of attitudes, values, goals and behaviors that influence program adoption and benefits. The materials for this last section were collected from social scientists' recall, from field notes, and monthly social scientist phone conversations. There are no particular selection criteria for these narratives beyond their illustrative power in the process of weatherization assistance. The narratives are presented in four sections that follow the stages of the weatherization process: client intake, assessment/audit; installation; and final inspection. The narratives are intended to give the reader the first hand experience of what it took to weatherize homes under the ARRA period of WAP, and what the process involved for the clients. Though this report is focused on conveying stories about the weatherization experience from multiple points of view, in the summary conclusion section we bring together three core takeaways alluded to in the stories from the field and summarized as follows:

\footnotetext{
${ }^{3}$ The number of interviews held and number of people interacted with at each site were undocumented.

${ }^{4}$ Details of the larger study's design are available in the "National Weatherization Assistance Program Process Field Study; Findings from Observations and Interviews at 19 Local Agencies Across the Country" prepared by APPRISE, the Energy Center of Wisconsin, Blasnik \& Associates, and Dalhoff Associates. May 12012.

${ }^{5}$ The U.S. Department of Energy's (DOE's) Weatherization Assistance Program (WAP) was created by Congress in 1976 under Title IV of the Energy Conservation and Production Act. The purpose and scope of the Program as currently stated in the Code of Federal Regulations (CFR) 10CFR 440.1 is "to increase the energy efficiency of dwellings owned or occupied by lowincome persons, reduce their total residential expenditures, and improve their health and safety, especially low-income persons who are particularly vulnerable such as the elderly, persons with disabilities, families with children, high residential energy users, and households with high energy burden" (Code of Federal Regulations, 2005).
} 
- Getting the program to the client has challenges both in the organizational component and in the client's way of dealing with change and uncertainty;

- The program is creating an environment that is supportive of improvements in the housing industry as staff and contractors gain new training and experience that may be applied elsewhere in the construction industry; and

- The changes made in each household and home may permeate communities in unanticipated ways. 


\section{METHODS AND DISCIPLINARY OVERVIEW}

\section{METHODS}

Participant observation is a method consisting of non-intrusive observing paired with rapport building. It was our intent to be as unobtrusive as possible, while at the same time being attentive to the cultural mores and social expectations in each specific region of the country and in each household. We attempted to create a sense of well-being and comfort according to those expectations.

\section{DISCIPLINARY OVERVIEW}

The tenets of participant observation have roots in anthropology, but each of the social scientists in this report brings a different disciplinary training: counseling psychology, organizational psychology, urban planning, environmental science, and cultural anthropology. So what each one of us saw and how we interpreted it was seen through those disciplinary lenses. We held monthly review conversations so we could describe what we were seeing and gain perspective on it from the others. In the process each of us encouraged new ways of seeing, but we also identified the differences brought by regional climate, construction practices and traditions, and by local economic and cultural conditions. Two of us have no experience in the field of weatherization. The observations from this uninitiated viewpoint were unconstrained by technical expectations about the "correct" procedures. They risked missing the significance of certain actions and decisions, but focused on the nature of communication. The other two have worked in the field of weatherization for decades, and bring knowledge of historic changes and standards in technical process. They risked stepping outside the strict observer role to express judgment of practices or knowledge of other programs, but were perceptive of the degree and meaning of partnership between agency/crew and client. Overlaps in disciplinary views allowed each of the scientists to see things they might not otherwise, and gave each of us greater latitude to interpret the range of behavior observed in the field. For example the organizational psychologist was attentive to effective organizational process as seen in relationships and subjective wellbeing, helping highlight interactions and communication effectiveness; the cultural anthropologist observed the influences of the unspoken rules and practices of culture and worldview on decisions and actions around energy use and home weatherization. 



\section{WHO ARE THE CLIENTS?}

The agencies live and work on the frontline of the current recession. On a daily basis, agency personnel see the effects of job outsourcing, unemployment, real estate devaluation and home foreclosures, the 2008 stock market crash, and currency flows. The clients we visited for this study experienced those and many other economic forces behind the current recession.

Indeed many home types and family configurations were represented in our sample. Examples...

- A little home in Florida: a fixer upper, purchased with state support by a single mother of a teenaged daughter, a lively selection of fresh paint in every room, and evidence of creative do-it-yourself and garage sale solutions.

- A trailer in rural Florida, perched in the middle of a field, owned by a widow relocated from New Jersey, now completely isolated from her family.

- A 5,000 square foot home with cathedral ceilings, and a commanding view of the foothills of the Smoky Mountains, recently inherited after the death of the parents saddled with estate taxes that have left the family bereft.

- A single story inner city Texas house with gaping holes in roof and floor, a walk-away too broken down to receive weatherization assistance, housing a family member in hospice.

- A two bedroom one-story house in Iowa owned by a retired couple that was so tiny, the husband had built shelves in several rooms to serve as storage spaces. The attic was so orderly and clean one could go up in bare feet.

- A two story home in Kansas occupied by an elderly couple who had to abandon the second floor because the windows were so ill fitting, and there were holes to the exterior walls.

- A mobile home in Maine owned by a young couple. The husband had renovated the trailer by replacing the skirting, installing new flooring, updating the appliances, replacing all the doors and windows, and painting the inside. The home was in such perfect condition there were almost no improvements to be made.

- A three story house in Massachusetts housing an extended family of South East Asian origin. Their call to the agency was triggered when one of the children's asthma became so bad that they were making frequent trips to the hospital.

- A family of nine people spanning four generations living in a one story six room house in Arizona. The house is heated by a wood stove and two gas heated wall units spewing dangerous levels of carbon monoxide.

The stories are both heartwarming and heartbreaking - people who were newly poor, recently widowed or divorced and all struggling with limited income and increasing energy bills. Most of the local weatherization agencies are Community Action Partnership (CAP) agencies. They were founded during the Great Society initiative of the President Johnson administration. They have been providing services for decades, and are among the most trusted institutions in their communities because they offer clients 
help at critical stages of life, from childhood into advanced age. Frequently, one program, say energy assistance, leads to referral to weatherization assistance. In other cases it could be interactions with agency staff in a Head Start program or in a food stamps program that would result in a referral to weatherization assistance.

The results of weatherization are striking in the quality of life improvements they have brought. There was the 80-year old woman who was able to open her window for the first time in eight years. There was the 60-year-old man whose trailer home cost him as much as $\$ 600$ each month to heat and who had expected to wait until he was 62 years old in order borrow money to pay for new windows. There was the young mother who suddenly qualified for services after taking in her three nephews when her sister lost custody of them.

As we observed the exchanges among client, agency staff, and crews, we noted that there was often a scattershot of information exchanged that did not have much if anything to do with weatherization but that helped discover shared ground and establish trust. For example we noted that many of the agency staff talked openly about living close to the poverty line, having lived in poverty and lifted themselves up with help from a CAP program, having family members owing their quality of life to an entitlement program. The director at one agency told us that just that day he had qualified for the subsidized lunches at his children's' school. Without exception, every program we observed talked about their explicit policy to never look down upon those they were serving. With that level of trust, the entire weatherization experience can be more comfortable for the client. Clients can be reluctant because of pride and unwillingness to admit the need for help, or they can be fearful of allowing strangers into the home. Some clients were afraid of being judged. At the same time, the staff at some agencies do talk about those who game the system, taking advantage of the program by applying many times, or by, for example, trying to coerce more improvements than the assessment recommends. But overridingly, the staff observes that those who try to take advantage are rare. Measures are taken to screen those cases out early in the intake stage at most agencies. It's costly to send out assessors and discover a "blowout" (non-qualifying).

\section{ALICIA $^{6}$}

Alicia is an African American woman in her mid-60s whose home was in a great state of decay. Paint is peeling from every wall and ceiling and the kitchen appliances must be more than 50 years old. This Wisconsin home had been owned by the client's mother, a single woman who raised the client and her siblings there.

On the walls were pictures of John F. Kennedy, Martin Luther King and Barack Obama. Religious iconography--paintings and statues of Jesus Christ and the Madonna--are also displayed prominently. Scanning the walls of her small living room, I notice a college diploma hanging over the worn sofa. This symbol of academic achievement challenged my assumption about the homeowner. When she catches me staring at the framed diploma, she tells me that she had completed her bachelor's degree in social work when she was in her mid-50s. She never entered the field because she chose to stay home and care for her dying mother. As a result of this decision, she was not able to escape the scourges of poverty and deprivation so widespread in her community. A proud woman, she recently accepted food from a food bank for the first time. She also received energy assistance but this support had been insufficient for the long cold winter of 2010 . Her home had no insulation, a fact she had been completely unaware of before the audit. "I really suffered for lack of education and knowledge about how to weatherize my home," she said.

\footnotetext{
${ }^{6}$ For the sake of privacy, all names in this report have been changed.
} 
Alicia was one of the few clients I encountered who took the energy saving recommendations to heart. She assured me that she would make changes to how she lived in her home, promising to use less lighting even though she confessed to "not liking to be in the dark." She also said she would "use more energy efficient light bulbs... Because of the insulation I will be able to keep my thermostat down to 65 degrees or less and I can use a fan unless the temperature exceeds 90 degrees."

To maintain contact with the world, Alicia was actively engaged as an online missionary, sharing her faith with people from around the globe. Sitting in front of her small fan and using her laptop computer, she was able to respond to people by email, praying for them and encouraging them with scripture as they worked through relationship, financial and other spiritual issues.

Alicia was grateful to the agency and the WAP program. The crews made her feel at ease and reassured her that she was "going to be warm...everything will be all right." She was truly overwhelmed that the weatherization actually happened because; as she said "I was on the list for a long time."

\section{MR. AND MRS. JONES}

Mr. and Mrs. Jones live in a nearly 100 year old house at the end of a three mile dirt road surrounded by Hackberry trees with an old trailer in the front yard and a large black dog on a rusty chain. Across the fields and on the grounds of the house is evidence of water holes and creeks but everything is very dry during our visit and the winds are extremely high, even creating a rare dust devil that gets the crew's and the client's attention. The absence of rain is on the client's mind a lot and a topic of every conversation. $\mathrm{He}$ is a former sharecropper in his eighties. He has trouble walking but still pays close attention to his land. Now he is the landowner. The fields are being cultivated by his children and an occasional land lease. He and his wife sit inside watching Mayberry RFD while the staff work. The evidence of the trouble they've had keeping warm is plain to see. They have piled up old clothes against the windows on the side of the house where the wind whips in off the prairie, and several windows in the kitchen are covered in plastic sheeting. The installation has been very disruptive of Mr. and Mrs. Jones' family life. The house is swathed in plastic with yellow tapes running here and there for lead safe practice. New walls and tunnels have been created and their possessions have been moved into a corner of the living room. Mr. and Mrs. Jones' daughters and grandchildren usually spend a lot of time at the house, and bring over lunch, but they don't come because of the installation work, so Mr. and Mrs. Jones go off to the kitchen and pull some leftovers from the fridge.

After lunch, Mr. Jones takes his walker and sits outside in the sun to warm up. He hooks his thumbs into the bib of his overalls, gazes over to the contractor team as they haul plywood boards, tape up the entryway with plastic sheeting, and run yellow caution stripping in front of the wall and begin hoisting sledge hammers. The contractor team is garbed in white lead safe suits and hoods. That is when Mr. Jones starts to talk. He mutters, "There they go again, the moon men!" He turns to me and says:

"Look at them running back and forth all the time. They work hard. I can't talk to them they're too busy!"

Mr. Jones has been a sharecropper all his life, his wife tells me. He knows what it means to work hard. When the crew takes a water break they stand next to Mr. Jones for a tobacco chew and a chat. As time goes by they discover that their families know each other from the county fairs. Mr. Jones' grandson had the winning rooster last year. When they get ready to go back to work the dog lopes by with a limp. He was bit by a rattlesnake, Mr. Jones tells them, and the conversation turns to hunting rattlesnakes for bounty; and eventually to shooting wild boar from helicopters. 



\section{CLIENT INTAKE}

Client intake at the agency was observed. The goal of the observations was to document the relationship that is initially established with the client and the information about the program that is provided to them.

I schedule production crews, work with contractors, review invoices and code them (contractor parts) answer the phone, answer client questions, try and make things move forward, not go backwards.

Intake staff, Montana

The person who answers the phone gets so much information from the client that by the time they get around to sending out an assessor the client feels like they're family!

Weatherization Director, Tennessee

The intake person must do more than collect information and direct clients to other programs. The intake function rests largely on the personality of the people in that position. It's a community-oriented function. Despite the fact that intake staff might not be fully informed about the needs of the inspector and the technical dimension of the weatherization process, they do seem to know what's going on in the community. This person plays a delicate role in the weatherization process, interfacing with a public who may be mistrustful of strangers or reticent or under-informed. This is the person who understands the unspoken rules and concerns of the community and who has instincts or experience that will help the client navigate the often-confusing path to services that exist outside the scope of the weatherization program.

Intake involves listening as a client presents one problem, but often arrives at or calls the agency with multiple issues. The intake person begins the process of connecting the client to the suitable programs and services, even if it is not a primary weatherization concern. For example, a client might be connected to food stamps, meals on wheels, or Head Start. A key component of the intake process is just being "neighborly", listening, paying attention to the client's needs and concerns, and helping the client take the next step. In essence, this person is sensitized to the client needs, is well informed and connected to the rest of the office, to other agency programs, and to other community services.

The intake person is also the gatekeeper of efficiency. Lots of calls come into the agencies, asking for the director or for services the agency does not provide. The intake person is in a position to guide the client to programs and services the client needs and is eligible to receive. The intake person acts as triage to make sure the calls and the walk-ins are able to connect with a person who can address their needs. In several agencies there was a strict procedure for intake, but the person doing intake took the lead on developing new forms to create a more efficient process for interacting with the clients, basing their practice on understanding the challenges a client faces when trying to understand the application process.

\section{JAMES}

Being an intake person requires innovation. James, who is entirely self-taught, created a visualizing technique for clients. Over the phone, he'd ask a client to sketch a square with a triangle perched atop, just like the way we all drew houses when we first took up a pencil. Once sharing the image, he could help the client visualize the work that the weatherization program can provide and what to expect from the process. 


\section{SHERRY}

Intake staff at other agencies can act as the liaison for field staff, the keeper of the daily schedules and contact information for clients and contractors. These staff often act as air traffic controllers, facilitating the process and helping field staff work more efficiently.

In addition to processing applications for weatherization, something that often required multiple contacts with a client, Sherry managed the travel logistics of her agency's crews, assisted the weatherization manager with assorted tasks, and helped clients get connected with other services in their service territory. Agency crews were on the road for most of the week, her manager's desk had stacks of paperwork that had to be processed and submitted to the state in a timely manner, and her clients rarely completed their applications correctly the first time. Sherry was never without something that had to be done "yesterday." Despite that, she expressed her desire to go out into the field to learn more about the weatherization process so she could better explain the process to her clients. 


\section{THE AUDIT}

The Social Scientist observed the audit process and the interaction between the auditor and client, with a particular focus on education and building a partnership with the client. Following completion of the audit, the Social Scientist interviewed the client to develop an understanding of how well the auditor communicated with the client and the client's perceptions of the program, as well as potential changes in client behavior as a result of education.

I try to put myself in [the client's] position and use examples to explain what I'm going to be doing and why. I can see when the light bulb comes on.

Auditor, Arizona

They crawl into the most intimate corners of people's homes, peeking into bedroom closets, attics and basements, the places people hide things so they can create order in the rest of their homes. On their bellies they squeeze into crawl spaces no more than three feet high and climb into attics through spaces just barely large enough. They begin their work in attics early in the morning to cope with the intense heat. They shine their flashlights in every corner, studying the movement of cobwebs to determine where air is escaping.

Because many agencies process client intake by mail or over the phone, the auditor is often the first faceto-face contact the client will have with the weatherization program. The auditor is key in assuring that the right measures are prescribed for the client's home and that the needs and issues of the client are fully understood. The auditor can successfully accomplish that task by observing, measuring, listening (both to what the client says or doesn't say) and communicating with the client.

\section{DJ}

DJ, a Hispanic young man in his late 20s, was new to the agency when we met. He served as both auditor and inspector. Though he'd only been at the agency for about two months, he had two years of weatherization under his belt with another agency. Ambitious and entrepreneurial, he is determined to make this program notable enough to garner the attention of state policymakers

I want to bring new ideas to this agency. It was borderline before I came. I'm idealistic.

I want to have the governor come to see our good work.

While still relatively inexperienced in weatherization, he saw gaps in his agency's program--the lack of client education being the most significant. Education at this agency, as he saw it, had little to do with helping clients realize long term savings and behavior changes. Because of this, he took it upon himself to create his own 'Client Education Check List.'

I want to provide a client education sheet to reinforce what I've told them.

But DJ's document has not been approved by his manager so he isn't allowed to distribute it to clients after all. What DJ lacks in experience, he makes up for in his commitment to help his customers:

I'm a positive person; I look at the clientele and realize that a lot of people don't know about the program; that's my priority - getting low-income people to go along. 
As a way of circumventing the bureaucratic red tape, DJ decides to make his own business cards.

I'll print my own if I have to so that I can leave my number and name with my clients.

\section{HARRY}

At the beginning of the day, the auditors, monitors, and weatherization manager at the agency meet at their shop to help installers prepare for the day. Conversation flows between supervisory staff and the crews, materials are assembled and questions and problems are addressed. The experience is a bit like a beehive before bees head off for the day to collect pollen. Harry is an auditor and one of the "go-to" people at the agency. He's someone that other staff feels comfortable talking to, asking questions and problem solving issues with.

Harry has worked for weatherization for eleven years, seven of those years as an auditor. Before becoming an auditor, he worked as an installer, worked in building maintenance for the city and as an electrical contractor. Harry says he was in "the building/fixing business" adding that he has the skills to figure things out on a job and be "a sufficer"... someone who can get things done using whatever information and materials are available.

Weatherization wasn't Harry's first career choice. He studied zoology and chemistry and wanted to become a dentist. Despite the fact that weatherization was not his intended career, Harry brings innovation, intelligence, understanding, and resourcefulness to the work he does.

Harry notes that many of the clients his agency serves lack the knowledge and money to do regular maintenance in their homes. Those issues contribute to the conditions weatherization crews often face when they attempt to provide weatherization services to their clients. Harry appears to feel empathy, not judgment, toward the clients he works with.

The best audits happen when an auditor and a client are both interested and engaged in the process and when there is an opportunity for information to flow between them. Bad audits occur when neither seems to care or, as in one case when the client sleeps through the audit. 


\section{INSTALLER}

The Social Scientist observes parts of measure installation to determine if and how the client is involved in the process, the communication between weatherization crews or contractors and the client, and interaction among the weatherization staff. Following the observation, the Social Scientist interviews the client to determine the client's assessment of the services delivered.

\section{JIM}

Jim, a slight man with skin weathered by years of working in the sun, was reticent when we first met. More comfortable in an attic, crawl space or outdoors among his fellow crewmembers, he seemed somewhat out of place in the spacious conference room where we conducted our interview. Reluctant at first to discuss his experiences at the agency, within minutes he eagerly shared his perspective on the WAP program.

Jim was new to the Northeast when he joined the agency two years ago, having spent most of his career in construction in the South. Like many of the crewmembers I met, Jim lived not much above the income level of the people he helped. A skeptic before joining the agency, he has become a vocal convert. "I really believe in what WAP does," he told me.

For people who can't afford high energy costs, WAP helps them conserve energy and it cuts costs for everyone. I agree with weatherization 100\%. I see every day how it helps people save money.

While he still encounters people whom he feels have "an entitlement mentality attitude," such as younger people who "want to soak money from the system," these are a rare exception. More common are the seniors who have worked all their lives and need help. He understands that the politics behind WAP are complicated and that some people feel weatherization is a waste of time. He hears negative things like "the world is running out of money," but, he says, "what we do is a really good thing."

Jim's ongoing training in areas such as weatherization boot camp, lead safety, energy efficiency, heating and air and framing structures provided Jim with skills and knowledge to be employable elsewhere. Given the current economy and the downturn in the housing market, the additional skills the agency provided give Jim the security that he wouldn't have to go on government assistance himself.

\section{MARTIN}

Martin is the operations manager for a contractor that provides installation services to the weatherization program in the State of Washington. Martin has worked for the contractor for six years, the last two years as the company's operations manager. He also has years of experience in the construction business. Martin did not to go through BPI training. He has years of experience using similar methods taught by BPI so when he sat for the exam he passed it the first time.

Martin is the sort of person who seems more comfortable with tools than with other people. Even so, he is pleasant, courteous, and informative when he communicates with his crew and with his clients. He has an open and comfortable relationship with the auditor from the weatherization agency. Getting accurate information from the auditor and the client to do his job efficiently the first time is critical because a call back to a job could mean losing money.

To stay in business and keep experienced crews from going elsewhere, a job has to be completed as efficiently and cost-effectively as possible. Because contractors do not receive a down payment for the 
weatherization jobs they do and are not paid until the job is satisfactorily completed, they carry the cost of a job and often need to pay crews before being paid by the weatherization agency.

When I first observed Martin, he was conducting a walk through with an auditor from the weatherization agency. He measured, actually re-measured and checked the auditor's numbers, he asked the auditor questions that would help him understand any obstacles he and his crews might encounter. He involved the client as much as possible and communicated all aspects of the job to his crew and to the client.

Margaret was one of Martin's clients. She is an older woman who lives alone in a one-story home located in a suburban neighborhood. She had lived in the house for a few years before being introduced to the weatherization program. Margaret has mental health issues that were not fully explained when the weatherization agency took the first call about Margaret's weatherization needs. The call came from a mental health official that offered to intervene, if necessary.

From the beginning, it was evident that Margaret would not be an easy client. Although she was pleasant, she didn't like strangers or anything new. At first she was resistant to nearly all the changes Martin and the weatherization auditor suggested. Her house did not have a working heating system for a couple of years before weatherization agency got involved. Her fireplace was her sole source of heat during those years. After some resistance on her part, a home repair program that the weatherization program agency works closely with, installed a new furnace. But during all the years without a heating system the home suffered a lot of moisture damage.

Her house also had back drafting issues caused, in part, by the same fireplace in Margaret's living room that had provided her with heat. Martin and the auditor suggested permanently closing off the fireplace or adding venting in the living room. Margaret resisted. She seemed to be afraid that without the fireplace she be without heat again if the new furnace stopped working. She didn't believe the installers when they told her the new furnace was unlikely to fail. She never accepted the suggestion to add venting in the living room.

In the end, after a lot of fighting she finally accepted most of the suggestions made during the weatherization process. Margaret reported that she was satisfied with the services she received and felt comfortable with the people who provided those services. She said that the people who helped her were very nice, always courteous, businesslike, and that they had a good sense of humor. Margaret said that she now understood that her water heater had been producing carbon monoxide, a substance that could harm her, and that she understood why measures like the new furnace and new electric water heater had been installed.

Martin turned out to be right that this weatherization job would be very expensive. Both the installation contractor and the auditor had put a lot of time into Margaret's home and into trying to help her understand the work they were doing. Martin had at least eight conversations with Margaret during the installation process. The auditor had also visited Margaret multiple times. Given the time it took to test, re-test, do the work, and address all of Margaret's concerns, Martin had the instinct pretty early in the job that the contractor would make no money on this job.

Despite that, Martin said that he thought that he and the weatherization auditor had made a good connection with Margaret and that they had done a good job helping a client who would never have been able to navigate the for-profit world on her own. Without the weatherization program, its partner home repair program, and contractors like Martin, it is easy to imagine that Margaret's home would still be filled with cracks in the ceiling, warped doors and cupboards and that Margaret would still be living with the silent killer, carbon monoxide. 


\section{NICK}

Most of the installers I met were independent contractors and had been in the construction trades for a long time. Working for the WAP agency was their "bread and butter." But for others weatherization was a recent addition to their business because new building and renovation work had slowed down. It was a means to keeping staff working and paying the bills.

One contractor stands out. He's in a family business with his two brothers. The company had specialized in custom-built homes but when the new construction slowed, they decided to take on some weatherization work because they thought it would be easy work. But it wasn't long before they discovered weatherization is complicated and requires hard work and skills they didn't have. So, they went off to get extra training and they bought specialized equipment.

If he leaves the weatherization market and returns to high-end construction projects his weatherization training and experience working with the WAP agency will improve his construction methods. Moreover, he has gained new perspective of his place in the community. Being able to improve the homes of people that are struggling has raised his own standards for what he offers his clients even if he can't bill for it. For example, he repaired one woman's kitchen cabinet, helped walk a dog for a client who was sick, and in one remarkable experience he even intercepted a burglar who broke in while he was on the job. 



\section{INSPECTOR}

The Social Scientist observed the final inspection to determine how education delivery is assessed, how the client is involved in the inspection process, and the additional education that occurs during the final inspection. Following the observation, the Social Scientist interviewed the client to determine how well the inspector communicated, the client's perceptions of the program, and potential changes in client energy usage behavior.

\section{LUCKY}

Lucky is an independent inspector who worked 20 years for a larger WAP and recently thought it was a good time to try starting his own home auditing business. He used the WAP work to fill in the slower private auditing he had hoped to be able to develop. His company is in Vermont.

\section{CORDELL}

As we approach the mobile home there are bits of metal siding and sheeting scattered around the lawn, a few holes are showing in the roof, and the entire underside can be plainly seen where the skirting was torn off. Patricia, the client, begins talking as soon as we step up on the porch and for the first part of the inspection all of us are a bit confused: the inspector, Patricia, the client, and me. Patricia, a tall and trim African American woman dressed in yoga pants and running shoes, had assumed Cordell was with the insurance company. She invites us in and talks for about five minutes about the damage we are seeing. "Should I file the claim through you?" she asks. In a flash Cordell figures out the misunderstanding and explains that he is the WAP inspector and that he is here to make sure the work was done properly by the installation crew. As soon as the installation was completed Patricia had gone to visit her brother in North Carolina and that was when the hurricane came through her trailer park, wreaking havoc and undoing some of the work of the installers, but not the critical ductwork that had been sealed up the inside, reducing the moisture.

The inspector thinks she is probably living as efficiently as she can. As he goes through and evaluates the work done, he sees little things that aren't listed in the work order. He tells Patricia,

I think they probably had some extra materials in the truck so they went ahead and installed the skirting to prevent the moisture from getting in and damaging the belly of the trailer. The insurance company will see to it that all that is reinstalled.

There's an exercise bike next to the front door. She laughs when I ask her if she uses it to hang clothes on. She points to the blood pressure cuff on the sofa and explains that she has had heart issues and has been off work.

I'm religious about my workout routine because of my heart condition.

When they tightened up the house she says her breathing got much better. She says,

I could see the house was leaky 'cause when the guy came by to test for leaks with the big fan he installed in the door, the linoleum raised up in the kitchen all the way to my waist. 
When Cordell ran it again for the inspection the linoleum raised up about a foot. He explains,

Mobile homes are leaky. There's nothing more to be done, but the sealing they did in your duct work will help your air quality. 


\section{SUMMARY AND FURTHER RESEARCH}

\section{TAKEAWAYS}

Three key takeaways emerge from the stories presented in this report and bear implications for further monitoring and study:

- Getting the people to the program: potential clients may have reluctance in applying for the program.

- Incubating weatherization business: Crew and staff learn new skills that may serve in future business.

- Getting the knowledge and experience back to the community: Each client experience impacts the surrounding community.

\section{Getting the People to the Program}

The program is funded by taxpayer dollars and is available to citizens in times of need. But it may take a long time before some have the courage or the stamina to submit an application and sustain the process. As we heard from clients themselves, and from many agency staff, those most in need of weatherization are often reluctant to ask for help.

They tried to offer me food stamps but those are supposed to make you feel like a second-class citizen and I refused. Weatherization is different. I paid taxes all my life and this is what the government has offered to do for me. So I said good! For my husband it is not so easy.

Client observed during weatherization installation, Texas

For some, there is fear of letting strangers into their homes. In some communities the elderly have been targeted by unscrupulous contractors, taking advantage of the growing demand for weatherization.

Private companies try to scam customers by selling weatherization services they're not qualified to install. If they come in first, then the Agency can't do a complete job. The private companies don't do as good work.

Texas Weatherization Manager and Inspector

Change is frightening to some, and as some of the stories in this report show, even though the agencies occupy a respected position in most of the communities, the work is disruptive of daily life and routines. Nowhere was that more dramatic than the experience of the former sharecropper, Mr. Jones watching the men in lead safe suits and muttering about the return of the "moon men."

\section{Incubating Weatherization Business}

The overall goals of weatherization - to save people money and save energy - have been advanced as the technology employed by weatherization has been introduced to technicians whose previous careers were in new home construction or trades like plumbing and carpentry. Now that the American Recovery and Reinvestment Act (ARRA) funding is gone, many of the staff that was hired to support higher production goals have returned to their previous jobs, or have lit out on new entrepreneurial paths. Equipped with new ways of looking at energy and housing and having developed skills to be more effective, they take 
the knowledge they gleaned from weatherization training and experience with them and use it in new home construction, rehab, or related fields. We heard agency staff dream of becoming entrepreneurs. Some talked of taking the new found knowledge and experience they garnered from their weatherization careers to expand existing businesses. Many planned on continuing to work in older homes now that new home construction was at a low ebb. Others talked about creating their own weatherization business. We came away with the sense that ARRA period WAP had acted as an incubator to emergent practices in a housing industry that had not previously used the tools or approaches that are standard practice in the weatherization program. A contractor from Texas who previously had only worked in new home construction was training his assistant because, he says

This is a growing industry and there will be lots of weatherization work in new home construction in the future.

\section{Getting the Knowledge and Experience Back to the Community}

Social scientists saw weatherization improvements across the national study that benefited not only the household but also the surrounding community. Many agencies were littered with thank you cards from clients at all stages of life and at all stages of the weatherization process, making it evident how their lives had been changed, and in turn making a public testament for others visiting the agency to see. Information about weatherization benefits and knowledge were spread in neighborhoods and through community centers by word of mouth within communities. In Knoxville, Tennessee for example, the agency reports that every neighborhood in the city has had at least one home weatherized; and in the neighborhood visited for this study as many as half the homes have been weatherized. In addition to successful weatherization experiences creating a viral spread of information about the program, there are small economic opportunities afforded to many recipients who increased their disposable income as a result of energy savings, and corrected unhealthy living conditions resulting in overall improvements in quality of life. Social scientists were also witness to many home visits where partnership was absent or limited. Failing to partner in the weatherization experience has many causes and are documented in the Process Field Study.

\section{ONGOING RESEARCH}

These takeaways indicate a place for continued research of the agencies, the staff, and the clients in the post ARRA period. Among the many questions to explore are:

- Emergence of new businesses?

- Lasting effects of weatherization measures on client behaviors and budgets?

- Generation of savings at the household level yielding economic activity within communities?

Longitudinal views are critical to identifying unanticipated or counterintuitive transformations in households and communities. This report is devoted to creating a record of some of the people served by WAP and of the attitudes and experiences of the various staff and contractors. ${ }^{7}$

\footnotetext{
${ }^{7}$ The Afterword tracks ongoing or proposed research to address these questions.
} 


\section{AFTERWORD}

The Personal Insights Report concludes with recommendations for further research into the economic and energy usage changes brought about by WAP. Oak Ridge National Laboratory (ORNL) provided the following updates about completed and ongoing research conducted as additional components of WAP.

- Before APPRISE and ORNL started the WAP Field Process Study, ORNL conducted a weatherization staff survey ${ }^{8}$ and a survey of individuals who received training at some of the weatherization training centers. Now that the Field Process Study is complete and ARRA funding has ended ORNL re-surveyed as many of those training recipients as they can locate, to see what they are doing with their lives and how the training is being put to use ${ }^{9}$.

- ORNL is launching a re-survey of clients. The survey respondents are a nationally representative sample randomly selected from lists of clients provided by the local weatherization agencies. The purpose of the resurvey is to see at least in the short-term whether their energy behaviors have changed.

- The University of Tennessee completed an analysis of the national economic impact of the program. The analysis focuses on jobs and economic activity study across 70 sectors of the economy ${ }^{10}$.

- ORNL will conduct a pilot persistence study to assess energy savings over a 10-15 year period in a small number of homes. This will not be a nationally representative sample.

\footnotetext{
${ }^{8}$ See Carroll, D., Berger, J., Miller, C., and Johnson, DB. 2014. National Weatherization Assistance Program Impact Evaluation: Weatherization Staff Survey. ORNL/TM-2014/323, Oak Ridge National Laboratory, Oak Ridge, Tennessee, September.

9 See Hawkins, B., Tonn, B., and Bensch, I. 2014. Findings from Survey Administered to Trainees of Weatherization Training Centers. ORNL/TM-2014/306, Oak Ridge National Laboratory, Oak Ridge, Tennessee, September.

${ }^{10}$ See Burton, M. et al. 2014. Macro-economic Impacts of the Weatherization Assistance Program for PY 2008. ORNL/TM2014/98, Oak Ridge National Laboratory, Oak Ridge, Tennessee, September.
} 